\title{
Assessment of Coagulants Efficiency in Water Treatment of Karoun
} River

\author{
Davoud Khodadadi Dehkordi, ${ }^{1,}{ }^{*}$ Heidar Ali Kashkuli, ${ }^{1}$ Kamran Mohsenifar, ${ }^{2}$ and Masoud \\ Sadeghi-Mianroudi ${ }^{1}$ \\ ${ }^{1}$ Department of Water Engineering and Sciences, Ahvaz Branch, Islamic Azad University, Ahvaz, IR Iran \\ ${ }^{2}$ Department of Soil Science, Ahvaz Branch, Islamic Azad University, Ahvaz, IR Iran \\ "Corresponding author: Davoud Khodadadi Dehkordi, Department of Water Engineering and Sciences, Ahvaz Branch, Islamic Azad University, Ahvaz,IR Iran. Tel: \\ +98-6134452040, E-mail: davood_kh70@yahoo.com
}

Received 2016 February 17; Revised 2016 July 01; Accepted 2016 July 04.

\begin{abstract}
Background: Many kinds of inorganic polymers have been developed, but, amongst them, polyaluminum chloride (PACl) is one of the most common kinds and has become most widely applied.

Objectives: The main objective in this research was the evaluation of three coagulants efficiency in the turbidity removal of Karoun river water in water treatment plant (WTP) of Kut-e Amir in different turbidity ranges of 0 to $>20000$ NTU.

Methods: For evaluation of the three coagulants efficiency (including polyaluminum chloride (PACL), aluminum sulfate (Alum) and ferric chloride) a jar-test was done for every turbidity range. In this research, coagulant aid (Besfloc) was added when samples turbidity were $>300$ NTU. Turbidity of samples were measured by the turbidity meter with the model of HACH2100N.

Results: According to the results, it was clear that PACL and Ferric Chloride had the better results in turbidity removal in comparison with Alum. Considering Ferric Chloride is cheaper than PACL and Alum, WTPs prefer to use Ferric Chloride. Economic analysis in WTP of Kut-e Amir showed that using Ferric Chloride achieved less costs in comparison with PACL and Alum.

Conclusions: Considering close and suitable results of Ferric Chloride and PACL in turbidity removal and more economical efficiency of ferric chloride than PACL, it's recommended to be used from ferric chloride with Besfloc when turbidity is under 6500 NTU. In the end, injection of coagulants different doses did not vary pH samples significantly.
\end{abstract}

Keywords: PACL, Alum, Ferric Chloride, Turbidity Removal

\section{Background}

Natural surface waters are usually polluted by organic or inorganic impurities. The colloidal dispersion due to electrostatic repulsive forces is stable. Water treatment plants remove these impurities by sedimentation and filtration, following the processing of water by coagulation/flocculation $(1,2)$. Considering the increasing of population and the raise of water consumption in cities, it is important to provide treated water properly. Actually, the need for drinking water of high quality is increasing, as the non-polluted water sources are continuously decreasing. The water treatment industry is amongst the most important industries in many countries such as Iran (3, 4). Turbidity is an important physical characteristic of water. Suspended matter or impurities like clay, silt, finely divided inorganic and organic matter, soluble colored organic compounds, plankton and other microscopic organisms are caused by it. Turbidity is also an important operational parameter in process control and can indicate problems with treatment processes, particularly coagulation/sedimentation and filtration. The turbidity levels in the water to be disinfected must be $<1.0$ NTU. High levels of turbidity can protect microorganisms from the effects of disinfection and may also indicate cryptosporidium, which can break through the filters and enter the water supply. Changes in turbidity are an important process control parameter. A very important step in water treatment that is essential for the removal of fine particulate matter is coagulation-flocculation process $(5,6)$. Coagulation, flocculation, sedimentation, filtration and disinfection are the most common treatment processes used in the production of drinking water. Coagulation/flocculation processes are of great importance in solid-liquid separation practice $(3,4)$. The coagulation process is used to destabilize colloidal material in water by the addition of a chemical agent. It requires rapid mixing to quickly disperse the coagulant and subsequently flocculation process. Flocculation is the formation of aggregates of the destabilized colloids and requires gentle mixing to allow effective collisions between particles to form heavy flocs, which can be removed from water by settlement (3). In other words, coagulation is the process of conditioning suspended solids 
particles to promote their agglomeration and produce larger particles that can be more readily removed in the subsequent treatment processes. The process of coagulation is complex and may involve several different mechanisms to achieve "destabilization", which allows particle agglomeration and enhances subsequent removal $(7,8)$. If these particles allowed to sediment, it may take several months or even a year to settle. For example, if the particle size is $0.0001 \mathrm{~mm}$ (colloidal particles) 755 days is required for settling. It should be noted that from an engineering viewpoint anytime more than a few hours is not acceptable $(8,9)$. Flocculation is the process of bringing the destabilized particles into contact with one another to form larger "flock" particles. These larger particles are more readily removed from the water in subsequent processes $(8,10)$. Nowadays by using usual salts of iron and aluminum, a new group of coagulants named inorganic polymers have been produced and used in many countries of the world especially China, Japan, Russia and Western European countries $(11,12)$. Many kinds of inorganic polymers have been developed including aluminum-based, iron-based, inorganic-inorganic composite flocculants, inorganic-organic composite flocculants and multifunctional composite IPFs (13-20). Amongst them, polyaluminum chloride (PACl) is one of the typical kinds and has become the most widely applied. The property and general coagulation behavior of inorganic polymers have been extensively investigated (12-14, 16, 19-23). Inorganic metallic salts makes the particles unstable by pressing double electrical layers around colloid particles, while polymers perform instability functions by absorption in colloid particle surface and making a bridge amongst the polymer particles (24). Takdastan et al. (25) evaluated PAC performance for removal of turbidity, COD, coliform bacteria and heterotrophic bacteria from water of Karoon river. The results showed that the maximum turbidity removal efficiency of 98.92 at 30 ppm was $10 \mathrm{~mL}$ while the maximum turbidity removal efficiency of 98.31 at $10 \mathrm{ppm}$ was $4 \mathrm{~mL}$. The maximum total coliform removal efficiency of 95.68 obtained for $10 \mathrm{ppm}$ in $10 \mathrm{cc}$ injected sludge volume. Besides, it was concluded that addition of returned sludge to flash mixing could reduce the turbidity of samples. Bazafkan et al. (26) evaluated poly aluminum chloride with powdered activated carbon as coagulant aid in TOC removal from the Karoon river. The results showed that the maximum removal in optimum pH of ferric chloride was $40 \%$ while $44 \%$ TOC removal was achieved at $\mathrm{pH} 6.5$ for poly aluminum chloride coagulant. In use of powdered activated carbon with optimum $\mathrm{pH}$ and concentration of ferric chloride, TOC reduction will increase with the increase of PAC concentration up to $90 \%$. Moreover, by addition of powdered activated carbon at similar conditions together with poly aluminum chloride $87 \%$ the reduction of TOC was occurred. Poly aluminum chloride was more effective in TOC removal than ferric chloride and PAC adsorption as coagulant aid improved TOC removal efficiency. Farhadi et al. (27) evaluated the efficiency of tragacanth coagulant aid in removing colloidal materials and suspended solids creating turbidity in the water of Karun River. The results showed that the best $\mathrm{pH}$ to remove turbidity is 5.5 to 7 , with the efficiency of 97.3\%. At $\mathrm{pH}=6$ and at the concentration of 30 $\mathrm{mg} / \mathrm{L}$, poly ammonium chloride has a maximum efficiency (90\%). Using tragacanthat concentrations of 1 and $4 \mathrm{mg} / \mathrm{L}$ along with alum at a concentration of $40 \mathrm{mg} / \mathrm{L}$ leads to turbidity removal of $81.75 \%$. Neisi et al. (8) evaluated the removal of turbidity and coliform bacteria from Karoun river water by natural coagulants aid (bread yeast) with PAC. Results showed that at high turbidity and applying 5 mgl-1 bread yeast coagulant aid and $15 \mathrm{mgl}^{-1}$ PAC coagulant, the highest turbidity removal percentage was to be $99.6 \%$ and coliform bacteria removal percentage was to be $99.5 \%$. Therefore, natural coagulant aid (bread yeast) is able to reduce turbidity and coliforms in Karoon river effectively. Ramavandi (28) evaluated the treatment of water turbidity and bacteria by using a coagulant extracted from Plantago ovate. The results showed that the FCE removed more than 95.6\% of all initial turbidity concentrations (50 - 300 NTU). High bacteriological quality was achieved in the treated water. FCE as an eco-friendly biocoagulant was revealed to be a very efficient coagulant for removing turbidity from waters. Mirzaiy et al. (29) evaluated the removal of turbidity, organic matter, coliform and heterotrophic bacteria by coagulants poly aluminum chloride from the water of the Karoun river in Iran. The results showed that the most optimal conditions for turbidity removal and microbial parameters efficiency by poly aluminum chloride were $\mathrm{pH}=$ 8 , flash mixing $=120 \mathrm{rpm}$ and the optimal doses of poly aluminum chloride were obtained as 10 and $30 \mathrm{ppm}$. The turbidity, total coliform, fecal coliform and heterotrophic bacteria removal efficiency under optimum condition of poly aluminum chloride application for dose 10 ppm were, respectively, 96.59\%, 90\%, 82.75\%, 84.17\% while turbidity, total coliform, fecal coliform and heterotrophic bacteria removal efficiency under optimum condition of poly aluminum chloride dose of 30 ppm were $99 \%, 94.65 \%, 88.94 \%$, $90.47 \%$, respectively.

\section{Objectives}

The main objective in this research was the evaluation of three coagulants efficiency including polyaluminum chloride (PACL), aluminum sulfate (Alum) and ferric chloride in the turbidity removal of the water in the Karoun 
river in the water treatment plant (WTP) of Kut-e Amir in different turbidity ranges of 0 to $>20,000$ NTU.

\section{Methods}

This research was conducted in WTP of Kut-e Amir, which was located in southeast Ahvaz, Iran. The Karoun River is the water resource and is providing the drinking water for southeast Ahvaz. This WTP has seven clarifier units that can purify $800,000 \mathrm{~m}^{3}$ /day of water from the Karoun River. Now, the coagulant that is used in WTP of Kut-e Amir is ferric chloride and in high turbidity conditions ( $>300$ NTU) Besfloc is used as a coagulant aid. In this research, three coagulants including polyaluminum chloride (PACL) $\left(\left[\mathrm{Al}_{2}(\mathrm{OH}) \mathrm{nCl}_{6}-\mathrm{n} \cdot \mathrm{xH}_{2} \mathrm{O}\right] \mathrm{m}(\mathrm{m} \leq 10, \mathrm{n}=3\right.$ $\sim 5)$ ), aluminum sulfate (Alum) $\left(\mathrm{Al}_{2}\left(\mathrm{SO}_{4}\right)_{3} \cdot 18 \mathrm{H}_{2} \mathrm{O}\right)$ and ferric chloride $\left(\mathrm{Fecl}_{3} \cdot 6 \mathrm{H}_{2} \mathrm{O}\right)$ were evaluated. For evaluating of three coagulants efficiency in this research, used from 11 different turbidity ranges from 0 to $>20,000$ NTU according to Table 1, considering different turbidities of Karoun river water. The coagulants injection ranges in every turbidity range achieved from the statistic evaluation of WTP of Kut-e Amir related to current ten years in this field. Table 1 shows the turbidity ranges and injection ranges of the coagulants and coagulant aid in this research.

For evaluating the efficiency of three coagulants, a jartest was done for every turbidity range. The jar-test apparatus with model of AQUALYTIC had six dishes (Figure $1 A)$. Essentially, about 7 to 30 jar-test were done for every turbidity range. After determination of water turbidity in every range (Table 1), a sample was transferred to jar-test dishes and the jar-test apparatus was started with a 180 to 190 rpm speed. Then, coagulants in minimum and maximum amounts in every turbidity range were added and after 15 to 20 seconds, coagulant aid in minimum and maximum amounts were added. After 1 minute, the jar-test apparatus speed was reduced to 50 to $60 \mathrm{rpm}$. Then, after 15 minutes, the apparatus was turned off and after 10 minutes it takes a $25 \mathrm{ml}$ sample in $1 \mathrm{~cm}$ depth of water surface in dishes for measuring turbidity. In this research, coagulant aid (Besfloc) was added when samples turbidity were $>$ 300 NTU. Turbidity of samples measured by turbidity meter with model of $\mathrm{HACH} 2100 \mathrm{~N}$ (Figure 1B).

\section{Results and Discussion}

\subsection{Evaluation ofJar-Test Results in Different Ranges of Turbidity}

4.1.1. Different Turbidity Ranges of < 50, 51 - 90 and 91 - 130 NTU

Jar-test results in turbidity ranges of $<50,51$ - 90 and 91 - 130 NTU with the minimum and maximum coagulants injection are shown in Figure 2.
According to Figure 2, Ferric Chloride had the best result in turbidity removal. Following, the PACL was very close to Ferric Chloride in turbidity removal but its effect was a little less than ferric chloride. Then, the effect of Alum in turbidity removal was the least. As the results showed, in low turbidity ( $<130$ NTU) and without coagulant aid the turbidity removal efficiency of Ferric Chloride was better than PACL, although they were very close together. However, in other studies like Takdastan et al. (25), Neisi et al. (8) and Mirzaiy et al. (29) in low turbidity ( $<130$ NTU) of Karoun River water the PACL showed an acceptable removal efficiency of turbidity.

\subsubsection{Turbidity Range of 131 - 300 NTU}

Jar-test results in turbidity range of 131 - 300 NTU with the minimum and maximum coagulants injection are shown in Figure 3.

According to Figure 3, PACL had the better turbidity removal efficiency than Ferric Chloride and Alum. Considering coagulant aid (Besfloc) was added when samples turbidity were $>300$ NTU, the results therefore showed that PACL in border of adding coagulant aid, showed better results. This can be a beginning for the better efficiency of PACL in turbidity removal in high turbidity ranges and without coagulant aid. In addition, the effect of Alum in turbidity removal was the least.

4.1.3. Different turbidity Ranges of 301 - 700, 701 - 1000, 1001 2000 and 2001 - 5000 NTU

Jar-test results in turbidity ranges of 301 - 700, 701 1000, $1001-2000$ and 2001 - 5000 NTU with the minimum and maximum coagulants injection are shown in Figure 4.

According to Figure 4, Ferric Chloride had the best result in turbidity removal. After that, PACL was very close to Ferric Chloride in turbidity removal but its effect was a little less than Ferric Chloride. Then, the effect of Alum in reducing turbidity was the least. In this research, in high turbidity ranges (> 300 NTU), coagulant aid (Besfloc) was added. Therefore, as the results showed, with adding of coagulant aid (Besfloc) the efficiency of Ferric Chloride in turbidity removal became better than PACL, although they were very close together.

\subsubsection{Turbidity Range of 5001 - 10,000 NTU}

Jar-test results in turbidity range of 5001 - 10,000 NTU with the minimum and maximum coagulants injection are shown in Figure 5.

According to Figure 5, ferric chloride had the better result in comparison with PACL in turbidity removal up to 6500 NTU. However, in higher turbidity (more than 6500 
Table 1. The Turbidity Ranges and Injection Ranges of the Coagulants and Coagulant aid

\begin{tabular}{lcc}
\hline Turbidity Range (NTU) & Coagulants Injection Range, ppm & Injection Range of Coagulant Aid, ppm \\
\hline$<\mathbf{5 0}$ & $1.00-1.50$ & 0 \\
$\mathbf{5 1 - 9 0}$ & $1.50-1.90$ & 0 \\
$\mathbf{9 1 - 1 3 0}$ & $2.40-2.90$ & 0 \\
\hline $\mathbf{1 3 1 - 3 0 0}$ & $3.00-3.50$ & 0 \\
\hline $\mathbf{3 0 1 - 7 0 0}$ & $3.00-3.50$ & $0.0087-0.01$ \\
$\mathbf{7 0 1 - 1 0 0 0}$ & $3.50-4.00$ & $0.025-0.053$ \\
$\mathbf{1 0 0 1 - 2 0 0 0}$ & $3.50-4.10$ & $0.05-0.0725$ \\
$\mathbf{2 0 0 1 - 5 0 0 0}$ & $3.50-4.50$ & $0.1-0.2$ \\
$\mathbf{5 0 0 1 - 1 0 0 0 0}$ & $4.00-4.55$ & $0.2-0.3$ \\
$\mathbf{1 0 , 0 0 1 - 2 0 , 0 0 0}$ & 4.60 & 0.3 \\
$>\mathbf{2 0 , 0 0 0}$ & 4.60 & 0.3 \\
\hline
\end{tabular}
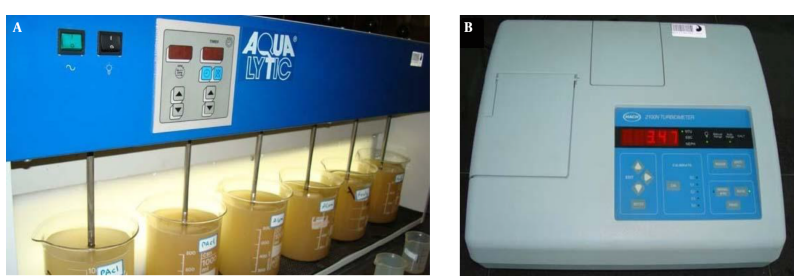

Figure 1. The Jar-Test Apparatus With Model of AQUALYTIC and the Turbidity Meter With Model of HACH2100N

Figure 2. Jar-Test Results in Turbidity Ranges of < 50, 51 - 90 and 91 - 130 NTU With the Minimum and Maximum Coagulants Injection

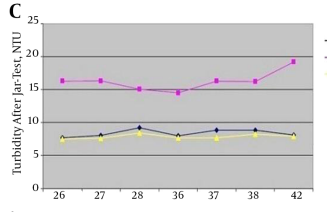

D

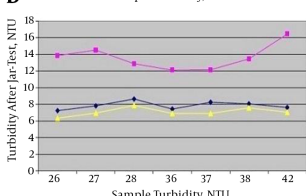

G

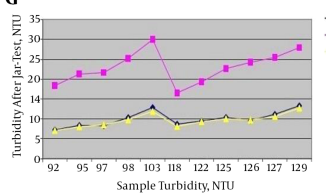

E

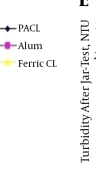

$\rightarrow$ - AAlum

F
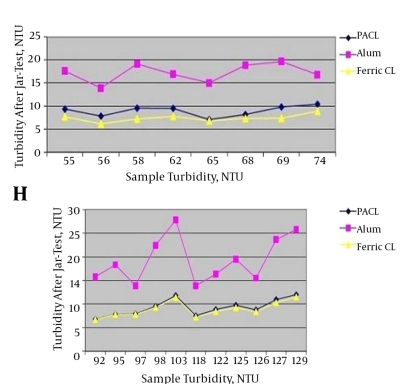

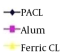

C, Jar-test results in turbidity range of $<50 \mathrm{NTU}$ with the minimum coagulants injection $(1 \mathrm{ppm})$ and without coagulant aid; D, Jar-test results in turbidity range of $<50$ NTU with the maximum coagulants injection (1.5 ppm) and without coagulant aid; E, Jar-test results in turbidity range of 51 - 90 NTU with the minimum coagulants injection (1.5 ppm) and without coagulant aid; F, Jar-test results in turbidity range of 51 - 90 NTU with the maximum coagulants injection (1.9 ppm) and without coagulant aid; G, Jar-test results in turbidity range of 91 - 130 NTU with the minimum coagulants injection (2.4 ppm) and without coagulant aid; H, Jar-test results in turbidity range of 91 - 130 NTU with the maximum coagulants injection $(2.9 \mathrm{ppm})$ and without coagulant aid.

NTU), the efficiency of PACL became better than ferric chloride in spite of adding coagulant aid. Also, the effect of Alum in turbidity removal was the least.
4.1.5. Different Turbidity Ranges of 10,001-20,000 and $>20,000$ NTU

Jar-test results in turbidity ranges of $10,001-20,000$ and $>20,000$ NTU with the minimum and maximum co- 
Figure 3. Jar-Test Results in Turbidity Range of 131-300 NTU With the Minimum and Maximum Coagulants Injection
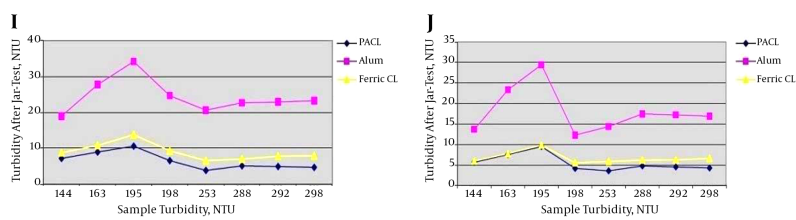

I, Jar-test results in turbidity range of 131 - 300 NTU with the minimum coagulants injection (3 ppm) and without coagulant aid; J, Jar-test results in turbidity range of 131-300 NTU with the maximum coagulants injection (3.5 ppm) and without coagulant aid.

Figure 4. Jar-Test Results in Turbidity Ranges of 301 - 700, 701-1000,1001-2000 and 2001 - 5000 NTU with the minimum and maximum coagulants injection
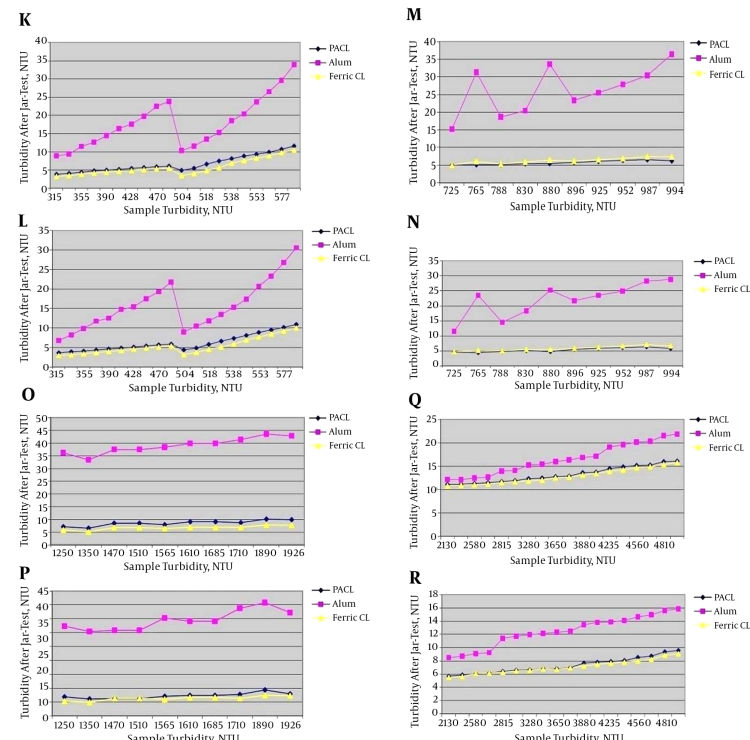

$\mathbf{N}$
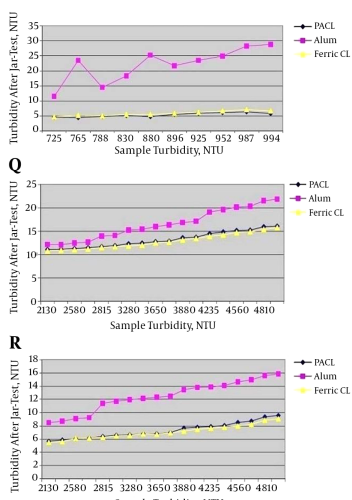

$\mathrm{K}$, Jar-test results in turbidity range of 301 - $700 \mathrm{NTU}$ with the minimum coagulants injection ( $3 \mathrm{ppm}$ ) and the minimum coagulant aid (0.0087 ppm); L, jar-test results in turbidity range of 301 - 700 NTU with the maximum coagulants injection ( $3.5 \mathrm{ppm}$ ) and the maximum coagulant aid ( $0.01 \mathrm{ppm}$ ); M, jar-test results in turbidity range of 701 -1000 NTU with the minimum coagulants injection $(3.5 \mathrm{ppm})$ and the minimum coagulant aid $(0.025 \mathrm{ppm})$; N, jar-test results in turbidity range of 701 - $1000 \mathrm{NTU}$ with the maximum coagulants injection ( $4 \mathrm{ppm}$ ) and the maximum coagulant aid ( $0.053 \mathrm{ppm})$; $\mathrm{O}$, jar-test results in turbidity range of 1001 - $2000 \mathrm{NTU}$ with the minimum coagulants injection (3.5 ppm) and the minimum coagulant aid (0.05 ppm); P, jar-test results in turbidity range of 1001 - 2000 NTU with the maximum coagulants injection (4.1 ppm) and the maximum coagulant aid $(0.0725 \mathrm{ppm}) ; \mathrm{Q}$, jar-test results in turbidity range of $2001-5000 \mathrm{NTU}$ with the minimum coagulants injection (3.5 ppm) and the minimum coagulant aid (0.1 ppm); R, jar-test results in turbidity range of 2001 - 5000 NTU with the maximum coagulants injection (4.5 ppm) and the maximum coagulant aid (0.2 ppm).

Figure 5. Jar-Test Results in Turbidity Range of 5001 -10,000 NTU With the Minimum and Maximum Coagulants Injection
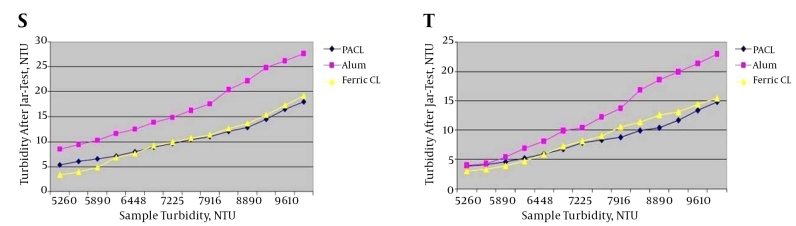

S, jar-test results in turbidity range of $5001-10,000$ NTU with the minimum coagulants injection (4 ppm) and the minimum coagulant aid (0.2 ppm); $\mathrm{T}$, jar-test results in turbidity range of $5001-10,000$ NTU with the maximum coagulants injection (4.55 ppm) and the maximum coagulant aid (0.3 ppm).

agulants injection are shown in Figure 6.

According to Figure 6, PACL had the better result in comparison with ferric chloride in turbidity removal, although they were very close together. According to Figures 

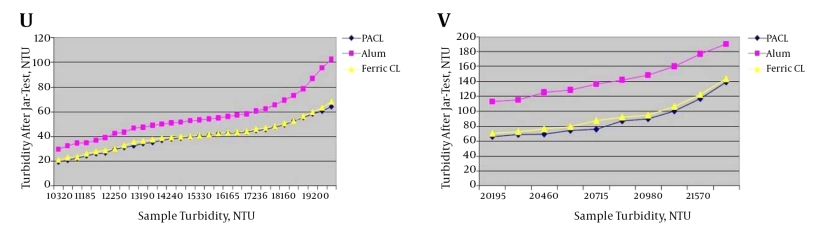

$\mathrm{U}$, jar-test results in turbidity range of 10,001 - 20,000 NTU with the maximum coagulants injection ( $4.6 \mathrm{ppm}$ ) and the maximum coagulant aid ( 0.3 ppm); $\mathrm{V}$, jar-test results in turbidity range of $>20,000$ NTU with the maximum coagulants injection $(4.6 \mathrm{ppm})$ and the maximum coagulant aid $(0.3 \mathrm{ppm})$.

2 - 6, in high initial turbidity ranges, turbidity after jar-test with adding of PACL, ferric chloride and coagulant aid were more than 5 NTU. Considering turbidity standard of drinking water in Iran (5 NTU), it is clear that with increasing initial turbidity and with injection of Table 1 doses the turbidity after the jar-test increases (more than 5 NTU). This result has been confirmed by Takdastan et al. (25); Neisi et al. (8) and Mirzaiy et al. (29). Therefore, it shows that in high initial turbidity, coagulants and coagulant aid doses in Table 1 are not enough and injection of Table 1 doses should be increased.

According to Figures 2 - 6, it was clear that PACL and ferric chloride had the better results in turbidity removal in comparison with Alum. This result has been confirmed by Baghvand et al. (3); Kord-Mostafapoor et al. (30) and Sid-Mohammadi et al. (31). Considering ferric chloride is cheaper than PACL and Alum, WTPs prefer to use from ferric chloride. Sid-Mohammadi et al. (31) recommended using ferric chloride for turbidity removal in comparison with PACL, because it was cheaper and more available than PACL. Economic analysis in WTP of Kut-e Amir showed that using of Ferric Chloride achieved less costs in comparison with PACL and Alum (Figure 7).

According to the results, costs of ferric chloride were less than PACL and Alum in WTP of Kut-e Amir. Thus, considering close and suitable results of ferric chloride and PACL in turbidity removal and more economical efficiency of Ferric Chloride than PACL, it's recommended to be used from ferric chloride with Besfloc when the initial turbidity is under 6500 NTU. When the turbidity is under 6500 NTU, there is not any exploitation problems for WTPs. However, according to Figures 5 and 6, in initial turbidity more than 6500 NTU, the efficiency of PACL was better than Ferric Chloride in the turbidity removal of the Karoun river water and it's recommended to be used form PACL in this conditions and ignore economic aspects. Due to the WTP of Kut-e Amir and high initial turbidities with efficiency reduction of ferric chloride, taking water from Karoun river is cut. In addition, the experiences have confirmed that with a pause in taking water from Karoun river even for one hour, water subscribers in Ahvaz city will have a shortage about $25,000 \mathrm{~m}^{3}$. So, it's important to use form the PACL with Besfloc in high initial turbidity (more than 6500 NTU) for achieving better results and better turbidity removal. Confirmed by Safaifar et al. (32); Wang et al. (12); Hart (33); Luan (34); Hongxiao and Zhaokun (35); Malhutra (36); O'Melia et al. (37); Takdastan et al. (25); Neisi et al. (8) and Mirzaiy et al. (29) PACL is the most effective coagulant.

Besides, Alum had the least effect on turbidity removal in entire experiment.Alum maybe cheaper than PACL but it never has suitable efficiency of turbidity removal in comparison with PACL. In addition, it should be considered that coagulation with Alum might increase aluminum concentration in drinking water as reported in many texts (38). Aluminum in coagulated drinking water has been regarded as a subject of human and environmental health concerns (39). Driscoll and Letterman (38) observed that the use of Alum could increase the total Al (III) concentration from $0.37 \pm 0.33 \mu \mathrm{mol} \mathrm{l}^{-1}$ in raw water to $1.8 \pm 0.33$ $\mu \mathrm{mol} / \mathrm{L}^{-1}$ in filtered water. Alum human health hazards have been well documented (3).

\subsection{Evaluation of $p H$ Variations Under Coagulants Injection}

Researches results have indicated that $\mathrm{pH}$ is one of the parameters, which causes turbidity removal efficiency to change, whereas, Volk et al. (40) indicated that the $\mathrm{pH}$ of coagulation was the most influential parameter in natural organic matter (NOM) removal from water. According to the results, injection of coagulants different doses (Table 1) did not vary pH samples significantly and samples of $\mathrm{pH}$ after injection of coagulants different doses was in the standard range $(10,33)$. Figure 8 shows $\mathrm{pH}$ variations under minimum and maximum doses and injection of coagulants respectively. This result is confirmed by Takdastan et al. (25); Neisi et al. (8); Farhadi et al. (27) and Mirzaiy et al. (29).

\subsection{Conclusions}

According to the results, PACL and ferric chloride had the better results in turbidity removal in comparison with 


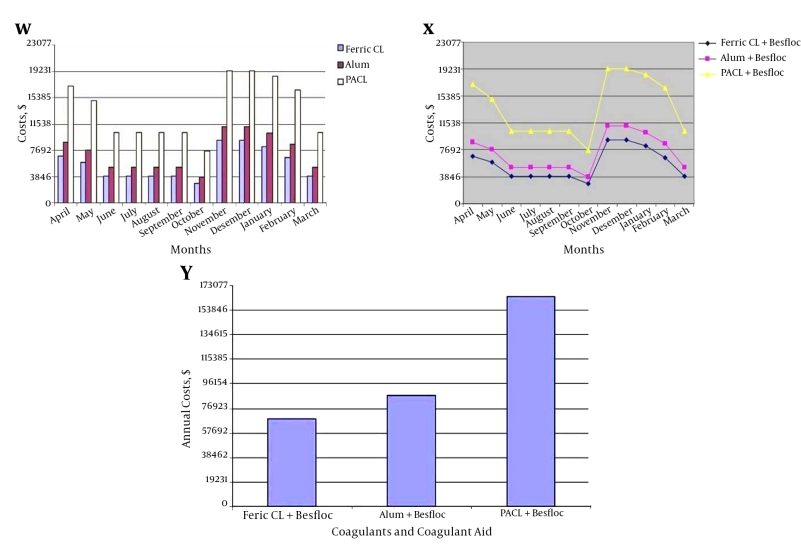

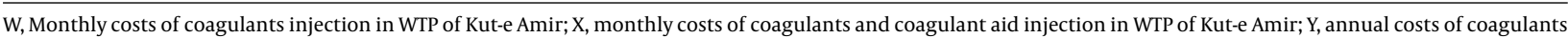
and coagulant aid injection in WTP of Kut-e Amir.

Figure 8. pH Variations Under Minimum and Maximum Doses Injection of Coagulants
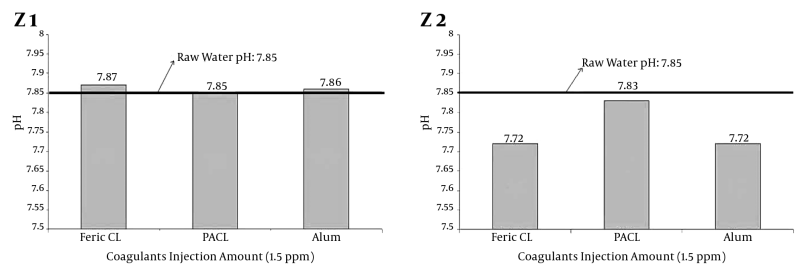

$\mathrm{Z1}$, pH variations under minimum dose injection (1.5 ppm) of coagulants; $\mathrm{Z2}$, pH variations under maximum dose injection (5 ppm) of coagulants.

Alum. Considering close and suitable results of Ferric Chloride and PACL in turbidity removal and a more economical efficiency of Ferric Chloride than PACL, it is recommended to be used from ferric chloride with Besfloc when turbidity is under 6500 NTU. Since the efficiency of PACL was better than ferric chloride in turbidity removal of Karoun river water in initial turbidity of $>6500$ NTU, it's recommended to be used from PACL in this condition and ignore economic aspects. Otherwise, it causes a pause in taking water from the river. In conclusion, injection of coagulants different doses did not vary $\mathrm{pH}$ of samples significantly.

\section{Acknowledgments}

The authors are thankful to Educational Assistance of Birjand University of Medical Sciences for their assistants and financially support.

\section{Footnotes}

Authors' Contribution: Reza Jafari, the co-supervisor and implementation of the project; and Hassan Zarghani was the supervisor.

Financial Disclosure: The authors declare that no competing interest is pertinent to this paper.

Funding/Support: This study was financially supported by a grant No. 4210 from Birjand University of Medical Sciences (BUMS).

\section{References}

1. Crittenden JC, Trussell RR, Hand DW, Howe KJ, Tchobanoglous G. MWH's water treatment: principles and design. John Wiley \& Sons; 2012.

2. Duan J, Gregory J. Coagulation by hydrolysing metal salts. Adv Colloid Interface Sci. 2003;100:475-502.

3. Baghvand A, Zand AD, Mehrdadi N, Karbassi A. Optimizing coagulation process for low to high turbidity waters using aluminum and iron salts. Am J Environ Sci. 2010;6(5):442-8.

4. Yukselen MA, Gregory J. The effect of rapid mixing on the break-up and re-formation of flocs. J Chem Technol Biotechnol. 2004;79(7):782-8.

5. World Health Organization . Guidelines for drinking water quality, vol 1 Recommendations. ; 2004.

6. World Health Organization . Guidelines for drinking water quality. ; 2006. 
7. American Water Works Association . Water treatment plant design. AWWA; 1971. Water treatment plant design.

8. Neisi A, Esteresh A, Takdastan A, Orooji N, editors. Removal of Turbidity and Coliform Bacteria from Karoon River Water by Natural Coagulants aid (Bread Yeast) with PAC. International Conference on Chemical, Environmental and Biological Sciences. 2015; pp. 18-9.

9. WHO . Guideline for drinking water quality, vol.2. ; 2007.

10. EPA. Turbidity through the Treatment Processes. Guidance Manual Turbidity Provisions. ; 1999.

11. Bertsch PM, Parker DR. Formation of the Al13 tridecameric polycation under diverse synthesis conditions. Environ Sci Technol. 1989;26:91421.

12. Wang D, Sun W, Xu Y, Tang H, Gregory J. Speciation stability of inorganic polymer flocculant-PACl. Colloids Surfaces A Physicochem Engin Aspects. 2004;243(1):1-10.

13. Matsui Y, Yuasa A, Furuya Y, Kamei T. Water treatment. Am Water Works Assoc. 1996;88(10):96-106.

14. Solomentseva IM, Gerasimenko NG, Barany S. Surface properties and aggregation of basic aluminium chloride hydrolysis products. Colloids and Surfaces A. Physicochem Engin Aspects. 1999;151(1):113-26.

15. Hong-Xiao T, Stumm W. The coagulating behaviors of Fe (III) polymeric species-II. Preformed polymers in various concentrations. Water Res. 1987;21(1):123-8.

16. Tang HX. Basic studies of inorganic polymer flocculants. Environ Chem. 1990;9(3):1-12.

17. Tang HX, Tian BZ, Luan ZK, Zhang Y. In: Chemical Water and Wastewater Treatment III. Tang HX, editor. Springer; 1994. pp. 57-69.Inorganic polymer flocculant polyferric chloride, its properties, efficiency and production.

18. Tang W, Liang K, Wang J, Du L, Zhang W. Effects of pHGF on hepatocyte DNA synthesis after partial hepatectomy in rats. JTongji Med Univ. 1998;18(1):25-7. [PubMed: 10806797].

19. Wang D, Tang H, Gregory J. Relative importance of charge neutralization and precipitation on coagulation of kaolin with PACl: effect of sulfate ion. Environ Sci Technol. 2002;36(8):1815-20.

20. Wang D, Tang H. Modified inorganic polymer flocculant-PFSi: its preparation, characterization and coagulation behavior. Water Res. 2001;35(14):3418-28. [PubMed: 11547863].

21. Gray KA, Yao CH, O'Melia CR. Water treatment. 87.;1995. p. 136.

22. Tang $\mathrm{H}$. The differences of behaviour and coagulating mechanism between inorganic polymer flocculants and traditional coagulants. Chemical Water and Wastewater Treatment IV. Springer; 1996.

23. Van Benschoten JE, Edzwald JK. Chemical aspects of coagulation using aluminum salts-I. Hydrolytic reactions of alum and polyaluminum chloride. Water Res. 1990;24(12):1519-26.

24. Gholamreza Nabi B, Toktam S, SHAHRIARI S. Plantago ovata efficiency in elimination of water turbidity.JWater Resource Protect. 2009;2009.

25. Takdastan A, Mirzaiy A, Alavi SN, Sekhavatjoo MS. Survey of PAC Performance for Removal of Turbidity, COD, Coliform Bacteria, Het- erotrophic Bacteria from water of Karoon River. Jundishapur J Health Sci. 2010;2(1):26-33.

26. Bazafkan H, Dattenbock C, Bohmdorfer S, Tisch D, Stappler E, Schmoll M. Mating type-dependent partner sensing as mediated by VEL1 in Trichoderma reesei. Mol Microbiol. 2015;96(6):1103-18. doi 10.1111/mmi.12993. [PubMed: 25757597].

27. Farhadi M, Takdastan A, Baghbany R. Evaluating the efficiency of tragacanth coagulant aid in removing colloidal materials and suspended solids creating turbidity in the water of Karun River.J Environ Health Sustain Dev. 2016;1(1).

28. Ramavandi B. Treatment of water turbidity and bacteria by using a coagulant extracted from Plantago ovata. Water Resources Indust 2014;6:36-50.

29. Mirzaiy A, Takdastan A, Alavi N, Mohamadian H. Removal of Turbidity, Organic Matter, Coliform and Heterotrophic Bacteria by Coagulants Poly Aluminium Chloride from Karoon River Water in Iran. Asian JChem. 2012;24(6):2389.

30. Kord Mostafapoor F. Effectiveness of three coagulants of polyaluminum chloride, aluminum sulfate and ferric chloride in turbidity removal from drinking water. Zahedan J Res Med Sci. 2008;10(2).

31. Sid-Mohammadi A, Zamini G, Mohammadi T, Salahshour N. Evaluation of Polyaluminum Chloride and Ferric Chloride efficiency in water treatment plant of Sanandaj city. The 9th National Congress on Environmental Health.

32. Safaifar M, Torabian A, Rashidi-Mehrabadi A. Impact evaluation of coagulant type on operation indices in direct filtration process. The 2 th National Conference on Operation and Maintenance of Water and Waste Water Systems. 2008. pp. 20-7.

33. Hart E. Optimizing Coagulant Conditions For The Worcester Water Filtration Plant. Worcester Polytechnic Institute; 2001.

34. Luan ZK. Theory and application of inorganic polymer flocculantpolyaluminium chloride. Beijing: Chinese Academy of Sciences; 1997.

35. Hongxiao T, Zhaokun L. Features and mechanism for coagulationflocculation processes of polyaluminum chloride. J Environ Sci. 1995;7(2):204-11.

36. Malhutra S. Polyaluminum chloride as an alternative coagulant. 20th WEDC Conference Colombo. Sri Lanka. 1994. pp. 289-91.

37. O'Melia PD, Jones WN. Concurrent review of the duration of antimicrobial prophylaxis in surgery. Hosp Pharm. 1989;24(5):369-72. [PubMed: 10318252].

38. Driscoll CT, Letterman RD. Chemistry and fate of $\mathrm{Al}$ (III) in treated drinking water. J Environ Engin. 1988;114(1):21-37.

39. Guida M, Mattei M, Della Rocca C, Melluso G, Meriç S. Optimization of alum-coagulation/flocculation for COD and TSS removal from five municipal wastewater. Desalination. 2007;211(1):113-27.

40. Volk C, Bell K, Ibrahim E, Verges D, Amy G, LeChevallier M. Impact of enhanced and optimized coagulation on removal of organic matter and its biodegradable fraction in drinking water. Water Res. 2000;34(12):3247-57. 